\title{
Identification and Characterization of the Phosphate-Solubilizing Bacterium Pantoea sp. S32 in Reclamation Soil in Shanxi, China
}

\author{
Qian Chen and Shanjiang Liu* \\ Institute of Plant Nutrition and Resources, Beijing Academy of Agriculture and Forestry Sciences, Beijing, China
}

\section{OPEN ACCESS}

Edited by:

Pier-Luc Tremblay,

Wuhan University of Technology,

China

Reviewed by:

Safdar Bashir,

University of Agriculture, Faisalabad,

Pakistan

Manoj Shrivastava,

Indian Agricultural Research Institute

(ICAR), India

*Correspondence:

Shanjiang Liu

liushanjiang54321@163.com;

liushanjiang@263.com

Specialty section:

This article was submitted to Microbiotechnology, Ecotoxicology

and Bioremediation,

a section of the journal

Frontiers in Microbiology

Received: 03 December 2018

Accepted: 04 September 2019

Published: 19 September 2019

Citation:

Chen Q and Liu S (2019)

Identification and Characterization

of the Phosphate-Solubilizing

Bacterium Pantoea sp. S32

in Reclamation Soil in Shanxi, China.

Front. Microbiol. 10:2171.

doi: 10.3389/fmicb.2019.02171
Phosphate solubilizing bacteria (PSB) can convert insoluble forms of phosphorus (P) to accessible forms. Five highly efficient PSB strains, H22, Y11, Y14, Y34, and S32, were screened and isolated from an alfalfa rhizosphere in heavy metal-contaminated reclamation area in Shanxi Province, China. Based on morphological observations, 16S rRNA sequencing, cellular fatty acid composition analysis, and the BIOLOG test, H22, Y11, and Y34 were identified as Pseudomonas sp., while Y14 and S32 were identified as Pantoea sp. Among them, S32 showed the highest P-solubilizing efficiency in culture medium containing $\mathrm{Ca}_{3}\left(\mathrm{PO}_{4}\right)_{2}$, lecithin, and powered phosphate rock. The culture medium conditions to obtain the highest P-solubilization efficiency were optimized as follows: the culture temperature was $30^{\circ} \mathrm{C}$; the incubation time was 5 days; the initial $\mathrm{pH}$ was 7.0; and glucose served as the carbon source. Furthermore, the P-solubilization efficiency of S32 in media containing $\mathrm{CaHPO}_{4}$, lecithin, phosphate rock (PR), $\mathrm{FePO}_{4}$, or $\mathrm{AlPO}_{4}$ was determined to be $18.38,3.07,0.16,0.51$, or $2.62 \%$, respectively. In addition, the acid and alkali phosphatase activities of S32 were tested as $6.94 \mathrm{U} / 100 \mathrm{~mL}$ and $4.12 \mathrm{U} / 100 \mathrm{~mL}$, respectively. The soil inoculation experiment indicated that inoculation with S32 resulted in an obvious improvement in the available $\mathrm{P}$ of both the experimental and reclaimed soil. The rice seedling growth experiment also suggested that the application of S32 significantly increased the plant height, biomass, root growth, and $\mathrm{P}$ uptake of rice in both experimental and reclaimed soil. Taken together, the isolated S32 strain showed high P-solubilization capacity for both $\mathrm{Pi}$ and $\mathrm{Po}$, and its ameliorative effect on reclaimed soil recovery provides the theoretical basis for crop development in the reclaimed soil of mine field.

Keywords: PSB, Pantoea sp., phosphatase activity, reclaimed soil, pot experiment

\section{INTRODUCTION}

Phosphorus $(\mathrm{P})$ is the second most important nutrient for plant growth, accounting for $0.2 \%(\mathrm{w} / \mathrm{w})$ of plant dry weight (Maharajan et al., 2018). P plays an irreplaceable role in the ecosystem by participating in most aspects of energy metabolism, nucleic acid and protein synthesis, and kinase regulation (Nesme et al., 2018). The average $\mathrm{P}$ content in soil is nearly $0.05 \%(\mathrm{w} / \mathrm{w})$ with the main two forms being inorganic $\mathrm{P}(\mathrm{Pi})$ and organic $\mathrm{P}(\mathrm{Po})$. Nevertheless, only $0.1 \%$ of $\mathrm{P}$ can be utilized by plants, rendering available $\mathrm{P}$ a restrictive factor for plant growth (Lambers and Plaxton, 2018). Phosphate anions in chemical fertilizer available to plants are extremely reactive and become 
fixed through interactions with $\mathrm{Ca}^{2+}, \mathrm{Fe}^{3+}$, and $\mathrm{Al}^{3+}$ ions in the soil to form insoluble phosphate salt complexes; however, the plant utilization efficiency for $\mathrm{P}$ in chemical fertilizers is only 5-25\% (Schnug and Haneklaus, 2016), leading to P enrichment in the soil and the loss of soil fertility. These realities make increasing the $\mathrm{P}$ utilization rate for plant growth an urgently needing situation.

Phosphate solubilizing bacteria (PSBs) convert unavailable $\mathrm{P}$ (both $\mathrm{Pi}$ and $\mathrm{Po}$ ) into available $\mathrm{P}$ to satisfy the requirements of plants through dissolution and absorption. According to the various P-dissolving patterns, PSBs can be divided into two classes: (1) Pi-solubilizing microorganisms that secrete organic acid to dissolve $\mathrm{Pi}$ compounds and (2) Po-mineralizing microorganisms that secrete phosphatase to enzymatically mineralize Po compounds. The application of both classes of PSBs in soil decreases the $\mathrm{pH}$ of the soil and forms a P-offering microarea around the plant rhizosphere, consequently improving the $\mathrm{P}$ supply available to the plant and strengthening the activity of other beneficial microorganisms, such as Rhizobium and Trichoderma. These applications promote the absorption of nutritive element ions.

Recently, following the development of energy bases and mines explored in Shanxi Province, China, a vast amount of cultivated land was contaminated with gangue, mineral waste, heavy metal, and rock debris. Approximately $68 \mathrm{~km}^{2}$ of cultivated land lost their crop productivity. Therefore, rational and scientific measures for soil reclamation in the mining area should be developed and applied without delay. In this study, to acquire a high PSB strain and improve the soluble $\mathrm{P}$ available to plants in the reclaimed soil, five PSBs were screened from the alfalfa rhizosphere soil of the reclamation area in the mining area of Xiao Yi town in Shanxi Province, China. Their P-solubilizing capacities under different conditions were investigated. The effect of PSB S32 on P solubility in the reclaimed soil recovery, plant and root growth, and the $\mathrm{P}$ uptake of rice were also evaluated. The present data suggest that the application of the isolated PSB would be of great importance in the bioremediation of reclaimed soil in mining areas.

\section{MATERIALS AND METHODS}

\section{Reclaimed Soil}

Approximately $200 \mathrm{~g}$ of soil samples with three replicates were taken from the rhizosphere of alfalfa in reclaimed soil of the Xiao Yi opencast mine area $(37.15 \mathrm{~N} ; 111.78 \mathrm{E})$ in Shanxi Province in July 2013. For each sample, the roots of vigorously growing plants were carefully dug. The bulk soils loosely bound on the roots were shaken off and discarded. The soil still attached to the plant roots was swept with a brush and collected as the rhizosphere soil sample (Zhu et al., 2017). The sealed soil samples were immediately placed in a refrigerated container. Each sample was used to isolate PSB immediately after bringing it back to the laboratory. The remaining part of the sample was then homogenized, air dried, and passed through a standard 100 sieve to analyze its physicochemical properties and $\mathrm{P}$ fractions. Triplicate samples were used for all experiments.

\section{Physical and Chemical Properties of Reclaimed Soil}

The reclaimed soil was aseptically separated from the roots to assess the physical and chemical properties. The $\mathrm{pH}$ was measured in a 2:1 water:soil suspension with a pH meter (Corey, 1971). Soluble P was extracted by the bicarbonate method and was then analyzed by the Molybdenum blue method (Colwell, 1963). The organic matter content was measured using the potassium dichromate colorimetric method (Nelson et al., 1996). The available potassium content was determined using the flame photometer method (Gammon, 1951). The content of nitrate $\left(\mathrm{NO}_{3}-\mathrm{N}\right)$ and ammonium nitrogen $\left(\mathrm{NH}_{4}{ }^{+}-\mathrm{N}\right)$ extracted by a potassium chloride solution was determined with an AutoAnalyzer 3 (AA3) equipped with $\mathrm{NH}_{4}{ }^{+}$and $\mathrm{NO}_{3}$ channels (SEAL, Germany) (Crooke and Simpson, 2010). Briefly, 1-2 g of soil that had passed a 2-mm sieve were placed into a $50 \mathrm{~mL}$ Erlenmeyer flask. Twenty $\mathrm{mL}$ of $\mathrm{KCl}$ solution was added to the flask. Samples were shaken on a horizontal shaker for $1 \mathrm{~h}$ and filtered through Whatman No. 2 filter paper. Filtrates were analyzed for $\mathrm{NH}_{4}^{+}-\mathrm{N}$, and $\mathrm{NO}_{3}-\mathrm{N}$. Extractions of all soils were repeated three times. Data are presented as the means \pm standard deviation. The physicochemical properties of the soil samples are shown in Table 1.

\section{Culture Medium}

Pi culture medium (Sahu and Jana, 2000) consisted of $10.0 \mathrm{~g}$ glucose, $0.5 \mathrm{~g}\left(\mathrm{NH}_{4}\right)_{2} \mathrm{SO}_{4}, 0.5$ g yeast extract powder, $0.3 \mathrm{~g} \mathrm{NaCl}$, $0.3 \mathrm{~g} \mathrm{KCl}, 0.03 \mathrm{~g} \mathrm{FeSO}_{4} \cdot 7 \mathrm{H}_{2} \mathrm{O}, 0.3 \mathrm{~g} \mathrm{MgSO}_{4} \cdot 7 \mathrm{H}_{2} \mathrm{O}, 0.03 \mathrm{~g}$ $\mathrm{MnSO}_{4} \cdot 4 \mathrm{H}_{2} \mathrm{O}, 5.0 \mathrm{~g} \mathrm{Ca}_{3}\left(\mathrm{PO}_{4}\right)_{2}, 1000 \mathrm{~mL}$ distilled water, and 20.0 g agar, $\mathrm{pH} 7.0-7.5$.

Po culture medium (Surange et al., 1997) consisted of $10.0 \mathrm{~g}$ glucose, $0.5 \mathrm{~g}\left(\mathrm{NH}_{4}\right)_{2} \mathrm{SO}_{4}, 0.5 \mathrm{~g}$ yeast extract powder, $0.3 \mathrm{~g} \mathrm{NaCl}$, $0.3 \mathrm{~g} \mathrm{KCl}, 0.03 \mathrm{~g} \mathrm{FeSO}_{4} \cdot 7 \mathrm{H}_{2} \mathrm{O}, 0.3 \mathrm{~g} \mathrm{MgSO}_{4} \cdot 7 \mathrm{H}_{2} \mathrm{O}, 0.03 \mathrm{~g}$ $\mathrm{MnSO}_{4} \cdot 4 \mathrm{H}_{2} \mathrm{O}, 1.0 \mathrm{~g} \mathrm{CaCO}_{3}, 0.2 \mathrm{~g}$ lecithin, $1000 \mathrm{~mL}$ distilled water, and $20.0 \mathrm{~g}$ agar, $\mathrm{pH}$ 7.0-7.5.

Nutrient agar culture medium (Deshmukh, 2007) consisted of $10.0 \mathrm{~g}$ peptone, $3.0 \mathrm{~g}$ beef extract, $5.0 \mathrm{~g} \mathrm{NaCl}, 1,000 \mathrm{~mL}$ distilled water, and 15-20 g agar, $\mathrm{pH} 7.2-7.4$.

Tryptic soy broth (TSB) culture medium (Mishra and Goel, 1999) contained $15.0 \mathrm{~g}$ tryptone, $5.0 \mathrm{~g}$ soy peptone, $5.0 \mathrm{~g} \mathrm{NaCl}$, and $1000 \mathrm{~mL}$ distilled water, $\mathrm{pH}$ 7.2-7.4.

BUG (BIOLOG Universal Growth agar) culture medium contained 57.0 g BUG agar culture (BLG.70101, BIOLOG) and $1000 \mathrm{~mL}$ distilled water, $\mathrm{pH}$ 7.0-7.5.

\section{Positive Control Bacteria}

The positive control bacterium Bacillus megaterium As1.223, which serves as a P-solubilizing microbial fertilizer in common use (Rodrìuez and Fraga, 1999; Chen et al., 2006), was supplied by the Microbe Collection Center of the Chinese Academy of Sciences (CAS).

\section{Isolation and Determination of the P-Solubilization Ability of Bacteria}

The bacterial isolation protocol and determination of the P-solubilization ability were performed as previously described 
TABLE 1 | Physicochemical characteristics and nutrients in reclamation and experimental soil.

\begin{tabular}{|c|c|c|c|c|c|c|c|c|c|c|}
\hline Sites & $\mathrm{pH}$ & $\begin{array}{c}\text { M.C } \\
(\mathrm{g} / \mathrm{kg})\end{array}$ & $\begin{array}{c}\text { O.M } \\
(\mathrm{g} / \mathrm{kg})\end{array}$ & $\begin{array}{l}\text { Nitrate N } \\
\text { (mg/kg) }\end{array}$ & $\begin{array}{c}\text { Ammonium N } \\
\text { (mg/kg) }\end{array}$ & $\begin{array}{c}\text { Available P } \\
\text { (mg/kg) }\end{array}$ & $\begin{array}{c}\text { Available K } \\
\text { (mg/kg) }\end{array}$ & $\begin{array}{l}\text { Total N } \\
\text { (mg/kg) }\end{array}$ & $\begin{array}{l}\text { Total P } \\
\text { (mg/kg) }\end{array}$ & $\begin{array}{l}\text { Total K } \\
\text { (mg/kg) }\end{array}$ \\
\hline 4-year Reclamation soil & 6.21 & 15.2 & 7.00 & 5.92 & 19.20 & 4.11 & 150.36 & 395.25 & 361.51 & 4625.84 \\
\hline Experimental soil & 4.0 & 22.3 & 26.54 & 8.12 & 29.35 & 6.39 & 355.90 & 676.22 & 480.36 & 5160.02 \\
\hline
\end{tabular}

MC, moisture content, OM, organic matter.

(Chen et al., 2014). Briefly, for isolation of bacteria, each soil sample were homogenized in sterile distilled water and serially diluted. Aliquots of each dilution were spread on Nutrient agar medium and incubated at $30^{\circ} \mathrm{C}$ for $24-48 \mathrm{~h}$. Colonies were selected on the basis of the development of a clear halo; the clones were further purified on Nutrient agar and TSB media. Once purified, each isolate was stored at $-80^{\circ} \mathrm{C}$ in the same medium with $20 \%$ (v/v) glycerol.

For P-solubilizing ability determination, the isolates were screened by culturing at $28^{\circ} \mathrm{C}$ on the media supplemented either lecithin (Po culture medium) or $\mathrm{Ca}_{3}\left(\mathrm{PO}_{4}\right)_{2}$ ( $\mathrm{Pi}$ culture medium). When the colonies appeared in 4-5 days, those causing a clear phosphate-solubilizing zone were selected out for further calculation. The size of phosphate-solubilizing zone was determined for each colony (Nair et al., 1995).

\section{Bacterial Colony and Mycelia Morphology Observation}

Candidate bacteria were inoculated on agar media and cultured for $48 \mathrm{~h}$ at $30^{\circ} \mathrm{C}$. The bacterial colony shape and color were observed, and bacteria were Gram stained. The morphology and size of the bacterial samples were observed by scanning electron microscopy (SEM) (S-3400N, Hitachi) at the Beijing Agricultural Biotechnology Center.

\section{Taxonomical Assignment}

16S rRNA sequencing and phylogenetic analysis were performed for taxonomical assignment. The primers sequences are displaying as follows: 27 F: 5'-AGA GTT TGA TCC TGG CTC AG-3', and 1492 R: 5' -TAC GGT TAC CTT GTT ACG ACT T-3'. Gene alignment was performed within the EzTaxon database, and a systematic phylogenetic analysis was performed using Mega 4.0 software. The phylogenetic tree was constructed by the neighbor-joining method with a bootstrap value of 1,000 .

\section{Accession Numbers}

The nucleotide sequence data reported in this paper appear with the following accession numbers (GenBank: MN294691, MN305765, MN305766, MN305767, and MN305768).

\section{Gas Chromatography (GC)-Fatty Acid Methyl Ester (FAMES) Analysis}

Gas Chromatography-Fatty Acid Methyl Ester in each isolated PSB was determined using a Sherlock automatic bacterial identification system. All the identification procedures were completed by the Beijing Agricultural Biotechnology Research Center. TSB culture medium was applied for bacterial excitation.
FAME profiles were then obtained by analyzing the samples on a GC (Agilent Technologies, United States) equipped with flame ionization detector (FID) and MIDI (R) Sherlock Microbial Identification System (MIDI Inc., Newark, DE, United States) software. FAMEs were identified according to their retention time, compared to a commercial standard mixture (MIS standard calibration, Part no. 1200-A) (Sasser, 1990).

\section{BIOLOG Identification}

The BIOLOG microbial ID system (Biolog Inc., Hayward, CA, United States) was used to further identify the physiological fingerprint of isolated bacteria strains, in accordance with the manufacturer's manual. Briefly, the strains were cultured in BUG media for $24 \mathrm{~h}$ generations at $30^{\circ} \mathrm{C}$ and resuspended in inoculating solution. Then, $100 \mu \mathrm{L}$ of culture was inoculated into each well of a Gen III MicroPlate and incubated at $33^{\circ} \mathrm{C}$ in the dark for 4-6 h or 16-24 h. The bacterial metabolites of PSBs were obtained using a spectrophotometer and then analyzed and compared with the BIOLOG database.

\section{Determination of the P-Solubilization Ability}

The S32 strain was cultured in Pi or Po media for 7 days with $\mathrm{Ca}_{3}\left(\mathrm{PO}_{4}\right)_{2}$, lecithin, $\mathrm{CaHPO}_{4}$, powdered $\mathrm{PR}, \mathrm{FePO}_{4}$, or $\mathrm{AlPO}_{4}$ as the $\mathrm{P}$ source. Non-inoculated medium was used as a blank control, while B. megaterium As1.223 was used as a positive control. The P-solubilization ability of the PSBs was tested three times independently. Each isolate was inoculated into a 200$\mathrm{mL}$ conical flask containing $100 \mathrm{~mL}$ of $\mathrm{Pi}$ or Po liquid medium (as described above) and then shaken $(160 \mathrm{rpm})$ at $30^{\circ}$. The suspensions were sampled at the indicated days postincubation. To remove the insoluble culture media, the suspensions were kept stationary for more than $1 \mathrm{~h}$. The acidity was assayed simply by reading on a $\mathrm{pH}$ meter, and the $\mathrm{P}$ availability was determined with the Molybdenum blue method (Watanabe and Olsen, 1965). Optimum pH (4-10), temperature $\left(20,25,30,35\right.$, and $\left.40^{\circ} \mathrm{C}\right)$, carbon source (Glu, Suc, Sta, Fru, Lac, Man, and Gly), and sodium content $(1-10 \%, w / v)$ for P-solubilization in liquid media were determined following the above method.

\section{Alkaline and Acidic Phosphatase Activity Detection}

Culture media supernatants from the lecithin-containing media were collected and detected using Alkaline and Acidic Phosphatase Kits (P0326 and P0321, Beyotime) in accordance with the manufacturer's instructions. B. megaterium As1.223 and non-inoculated medium served as positive and negative controls, respectively. The phosphatase activity of $1 \mathrm{mg}$ of phenol 
production after a 15 min reaction with the matrix at $30^{\circ} \mathrm{C}$ in $100 \mathrm{~mL}$ of medium was defined as one King-Armstrong unit.

\section{Soil Experiment}

The S32 strain was cultured in $100 \mathrm{~mL}$ of TSB medium at $30^{\circ} \mathrm{C}$ for $36 \mathrm{~h}$, and then cells were harvested by centrifugation at $5000 \mathrm{rpm}$ at $4^{\circ} \mathrm{C}$ for $5 \mathrm{~min}$ and adjusted to $1 \times 10^{8}$ cells $/ \mathrm{mL}$ in sterile deionized water by dilution and plating. The experimental and reclaimed soil were autoclaved, and the initial available $\mathrm{P}$ was about $6.41 \mathrm{mg} / \mathrm{kg}$ and $4.05 \mathrm{mg} / \mathrm{kg}$. For the experimental group, $600 \mathrm{~g}$ of soil was soaked with the above S32 strain suspensions $\left(10^{8}\right.$ cells $\left./ \mathrm{mL}\right)$ for $30 \mathrm{~min}$. Non-inoculated soil served as a negative control. The available $\mathrm{P}$ in the soil of each treatment group was determined at 10 and 30 days post administration, and the experiment was performed independently three times.

\section{Rice Seedling Growth Experiment}

Sterilized deionized water-washed 7-day-old Malaysia MR-219 rice seedlings were grown in experimental and reclaimed soil. For the experimental group, homogenous seedlings were soaked with S32 strain suspensions $\left(10^{8}\right.$ cells $\left./ \mathrm{mL}\right)$ for $30 \mathrm{~min}$. Then, three seedlings were sown in each plastic pot. The plants were grown under natural growth conditions, maintaining a $20 \%$ absolute water content. Rice seedlings were harvested 21 days after sowing. Approximately $5 \times 10^{8} / \mathrm{mL}$ of live washed bacterial S32 cells were used as inoculum in each bacterial treatment.

The root morphology of the MR-219 rice was determined using a root scanner (Expression 1680, Epson). Total root length $(\mathrm{cm})$, total surface area $(\mathrm{cm} 2)$ and total volume $(\mathrm{cm} 3)$ were quantified using a scanner (Expression 1680, Epson) equipped with a $2 \mathrm{~cm}$ deep plexiglass tank $(20.30 \mathrm{~cm})$ filled with $\mathrm{H}_{2} \mathrm{O}$ (El Zemrany et al., 2007). The scanned data were processed by Win-Rhizo software (Regent Instruments Inc.).

\section{Organic Acid Evaluation}

Approximately $20 \mathrm{~mL}$ of the samples from each treatment were injected into HPLC with a UV detector set at $210 \mathrm{~nm}$. A Rezex ROA-organic acid " $\mathrm{H}^{+}$" (8\%) column was used, and the mobile phase was $0.005 \mathrm{~N} \mathrm{H}_{2} \mathrm{SO}_{4}$ with a flow rate of $0.17 \mathrm{~mL} / \mathrm{min}$.

\section{Statistical Analysis}

All the data were processed with SPSS 13.0 statistical software and are presented as the mean \pm standard deviation (SD). Student's $t$-test analysis and one-way ANOVA was used to calculate the data variance, and $P<0.05$ represents a significant difference.

\section{RESULTS}

\section{Screening and Isolation of the PSBs}

A total of 20 bacteria with a considerable transparent zone were screened and isolated by colony formation on Pi and Po plating media (Figure 1A). Among them, there were five bacteria with a diameter of the transparent zone (D) to colony (d) ratio larger than 1.50, as formed on Pi plating media, and a ratio of $\mathrm{D} / \mathrm{d}$ on Po plating media larger than 1.90. Isolation S32 displayed the
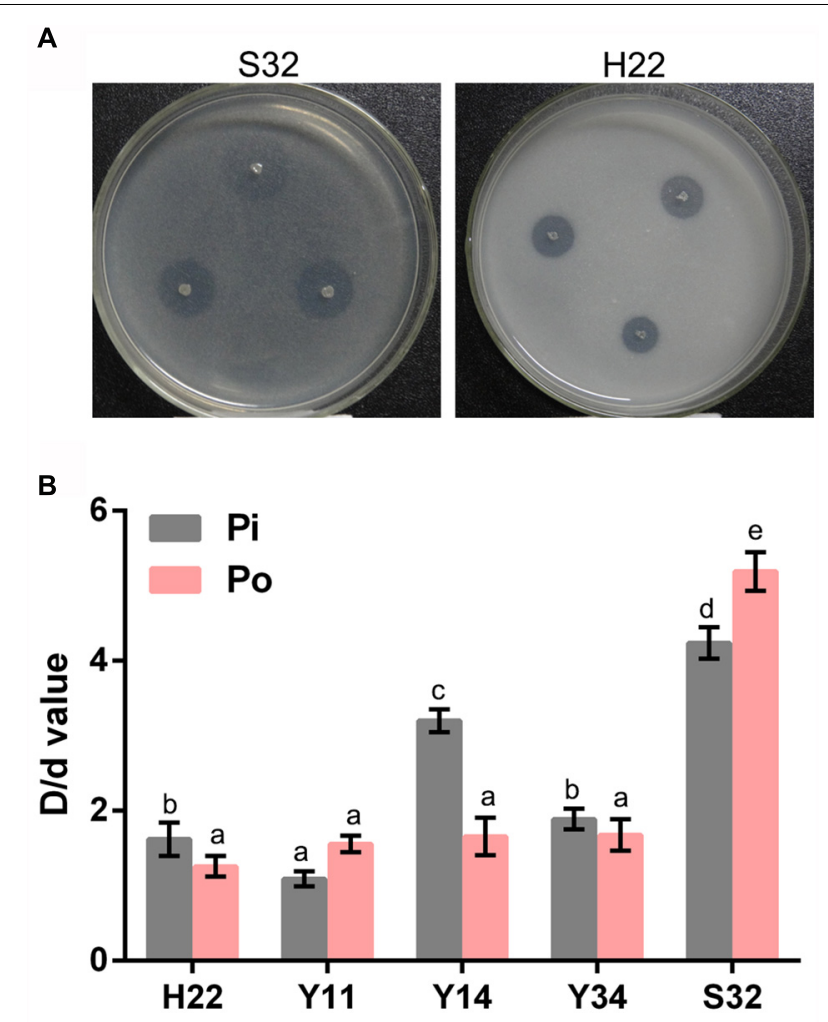

FIGURE 1 | The bacterial colonies of PSBs. (A) The bacterial transparent halos of S32. (B) Comparison of the D/d value of each PSB. Different lowercase letters indicate significance at the $5 \%$ level.

highest D/d ratio on Pi medium and Po medium, 4.24 and 5.19, respectively, (Figure 1B).

Five PSBs (H22, Y11, Y14, Y34, and S32) formed semicylindrical colonies that were emulsus, yellow, opaque, glossy, and orderly. SEM revealed that the thallus was rhabditiform, non-spore forming, and gram-negative with a size of $0.5-0.6 \mu \mathrm{m} \times 0.6-1.6 \mu \mathrm{m}$ (Figure 2).

\section{Characterization of PSBs}

The DNA gene size of H22, Y11, Y14, Y34, and S32 was approximately $1.5 \mathrm{~kb}$. The alignment of the 16S RNA of five PSBs was performed with the EzTaxon database, and a phylogenetic analysis was performed with highly homologous strains as reference bacteria. We found that Y14 was homologous to Pantoea calida $1400 / 07^{\mathrm{T}}$ (GQ367478) (Popp et al., 2010) (99.79\%) (Figure 3A). H22, Y11, and Y34 were highly homologous to Pseudomonas vancouverensis ATCC $700688^{\mathrm{T}}$ (AJ011507) (Mohn et al., 1999), Pseudomonas mandelii CIP $105273^{\mathrm{T}}$ (AF058286) (Verhille et al., 1999), and Pseudomonas frederiksbergensis JAJ28 ${ }^{\mathrm{T}}$ (AJ249382) (Andersen et al., 2000), respectively, (Figure 3B). S32 was highly homologous to Pantoea sp., of which Pantoea rodasii LMG $26273^{\mathrm{T}}$ (JF295053) (Brady et al., 2012) displayed the highest similarity (99.94\%). S32 clustered with LMG $26273^{\mathrm{T}}$ and LMG $26275^{\mathrm{T}}$ in the phylogenetic tree (Figure 3C). 

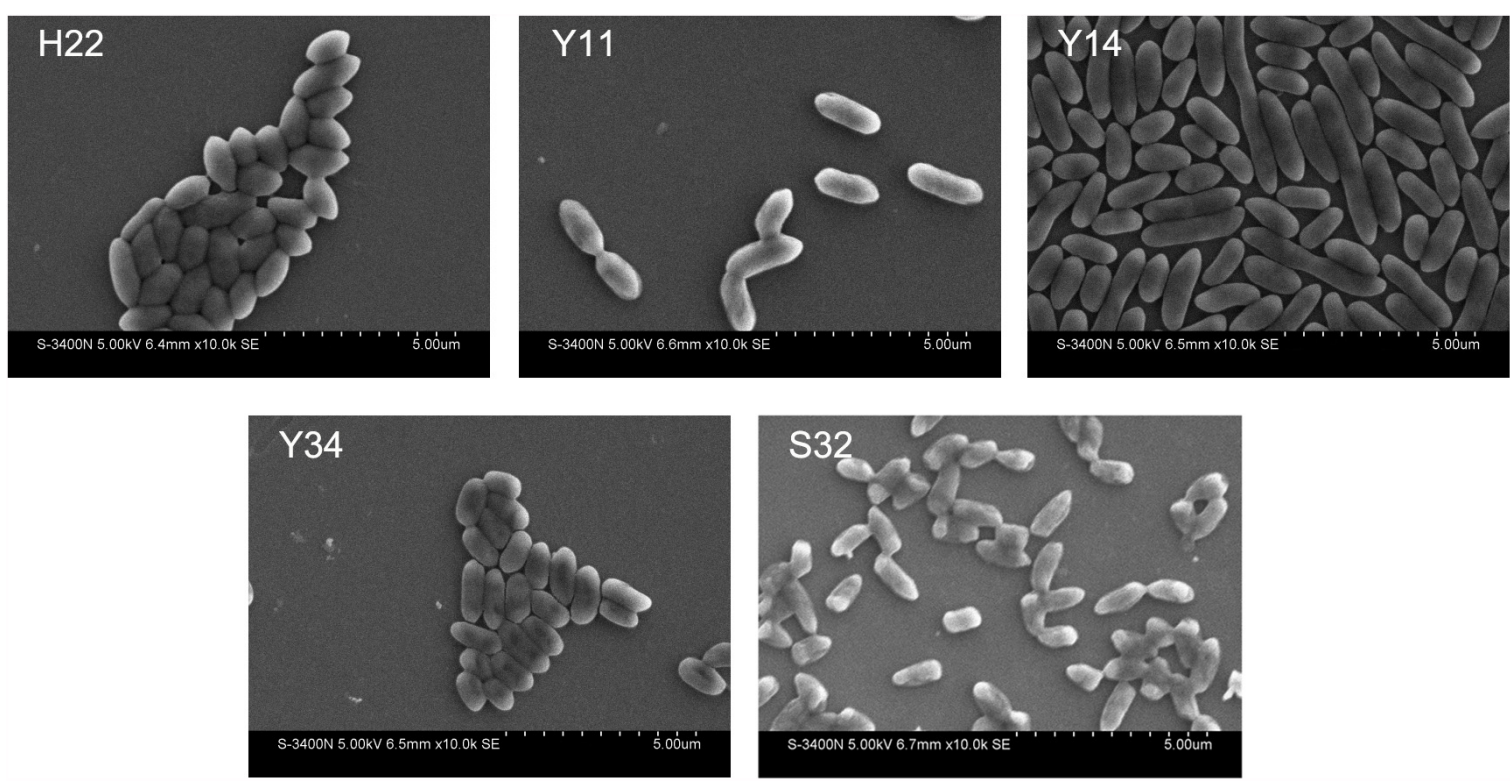

FIGURE 2 | Morphology of each PSB by SEM $\left(\times 10^{4}\right)$.

A

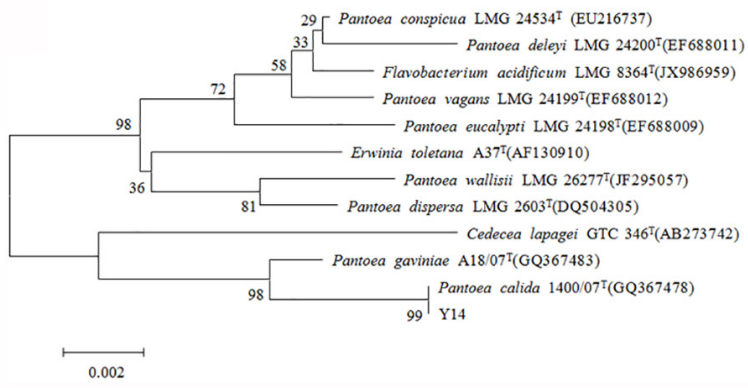

B

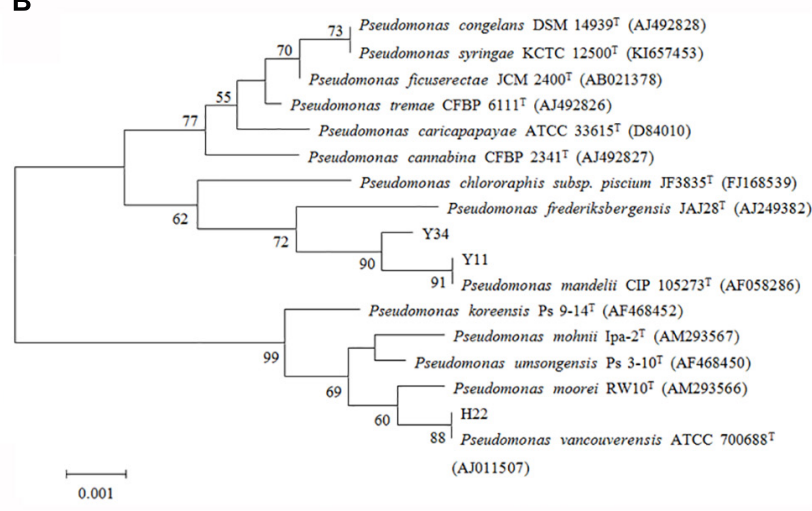

C

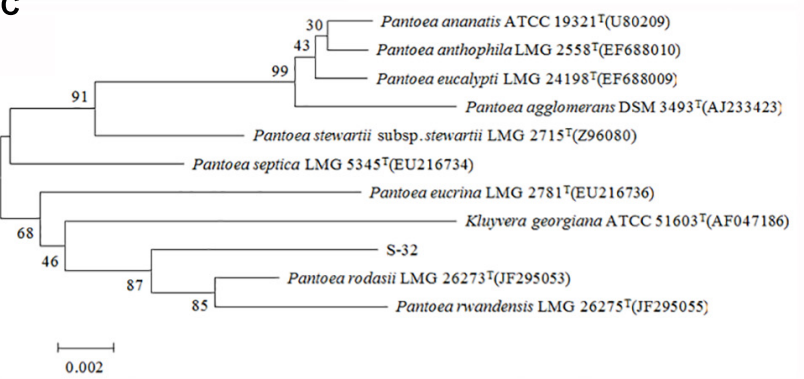

FIGURE 3 | Phylogenetic tree of maximally similar species representing strains Y14 (A), Y11, Y34, H22 (B), S32 (C).

\section{Stress Resistance Test of Five PSBs}

Each PSB displayed high tolerance to a broad range of temperatures, $\mathrm{pH}$ values, and sodium concentrations, especially for S32. Its tolerance ranged from 4 to $37^{\circ} \mathrm{C}, \mathrm{pH}$ values of $4-11$, and sodium concentrations of 2-10\% (Supplementary Table S1).

\section{Fatty Acid Composition Analysis}

Fatty acids were mainly distributed in the cell membrane as the basis of the lipids and lipopolysaccharides. The fatty acid composition data were analyzed according to the Microbial Identification System: the characteristic peak value $>1 \%$ was 
$\mathrm{C}_{12: 0}, \mathrm{C}_{16: 0}, \mathrm{C}_{17: 0}$ cyclo, and $\mathrm{C}_{18: 1 \omega} \mathrm{cc}$ in the second and third peaks. The major characteristic peak contained $\mathrm{C}_{12: 0}$ and $\mathrm{C}_{18: 1 \omega}$ $7 \mathrm{c}$, and the third peak occupied 27.6, 14.6 , and $25.3 \%$ of that of the whole-cell component, which was consistent with that of LMG $26273^{\mathrm{T}}$ and LMG $26275^{\mathrm{T}}$ (Supplementary Table S2).

\section{BIOLOG Identification}

To further characterize the S32 strain, which showed the highest P-solubilizing capacity among all the isolated PSBs, a BIOLOG test was performed to identify its species. The alignment results of strain S32 displayed good agreement with Pantoea cypripedii at $22 \mathrm{~h}$ after culturing at $33^{\circ} \mathrm{C}($ SIM value $=0.589)$. The BIOLOG reaction results ultimately confirmed that $\mathrm{S} 32$ was a Pantoea sp., which was consistent with our $16 \mathrm{~S}$ rDNA sequence analysis (Supplementary Table S3).

\section{P-Solubilizing Efficiency of Five PSBs With Different $\mathbf{P}$ Sources}

To screen out the bacterium with the highest P-solubilizing efficiency in $\mathrm{Pi}, \mathrm{Po}$, and powdered $\mathrm{PR}$, the five selected bacteria were inoculated into $100 \mathrm{~mL}$ of liquid media supplemented with either $\mathrm{Ca}_{3}\left(\mathrm{PO}_{4}\right)_{2}$, lecithin, and powdered PR. For $\mathrm{Ca}_{3}\left(\mathrm{PO}_{4}\right)_{2}$, the P-solubilizing efficiency of S32 reached $24.19 \%$, which was nearly quadruple that of the positive control B. megaterium As1.223. The available $\mathrm{P}$ in the medium was $1256.67 \mathrm{mg} / \mathrm{L}$, while the $\mathrm{pH}$ value was reduced by 3.51 , which was double that of $A s 1.223$ (Figure 4A). The P-solubilizing efficiency for lecithin was $2.47 \%$, which was 1.5 times that of the positive control As1.223. The available $\mathrm{P}$ content in the Po medium was $13.05 \mathrm{mg} / \mathrm{L}$, and the $\mathrm{pH}$ value decreased by 3.89 (Figure 4B). However, with respect to $\mathrm{PR}$, the five PSBs showed a degree of efficiency similar to that of As1.223 (Figure 4C).

\section{P-Solubilization Capability of S32 Under Different Experimental Conditions}

To determine the effect of inoculation time on the P-solubilization rate of S32, media containing $\mathrm{Ca}_{3}\left(\mathrm{PO}_{4}\right)_{2}$ was inoculated with S32 for different time points. The P-solubilization efficiency of S32 rapidly reached $23.91 \%$ at 24 h postinoculation (PI) and increased slowly to its maximum (24.61\%) at day $5 \mathrm{PI}$. The content of available $\mathrm{P}$ in the medium reached $1204.67 \mathrm{mg} / \mathrm{L}$ at $24 \mathrm{~h} \mathrm{PI}$ and then slowly peaked at $1332.33 \mathrm{mg} / \mathrm{L}$ at day $7 \mathrm{PI}$. The $\mathrm{pH}$ in the medium quickly decreased to 3.40 at $24 \mathrm{~h} \mathrm{PI}$, which was maintained for the following 6 days (Figure 5A).

The P-solubilizing efficiency of S32 on different $\mathrm{P}$ sources, $\mathrm{Ca}_{3}\left(\mathrm{PO}_{4}\right)_{2}, \mathrm{CaHPO}_{4}$, lecithin, $\mathrm{PR}, \mathrm{AlPO}_{4}$, and $\mathrm{FePO}_{4}$, was 24.09, $18.38,2.47,0.19,0.51$, and $2.62 \%$, respectively. Each condition yielded a rate significantly higher than the B. megaterium As 1.223 positive control. The $\mathrm{pH}$ value decreased by 3.51, 2.68, 3.89, $3.58,3.46$, and 4.03 in these types of media, respectively. Thus, the efficiency of P-solubilization on $\mathrm{Ca}_{3}\left(\mathrm{PO}_{4}\right)_{2}$ was the greatest compared to the other $\mathrm{P}$ sources tested (Figure 5B). Notably, S32 showed significantly higher P-solubilizing efficiency than B. megaterium As1.223 positive control.

By using glucose, sucrose, starch, fructose, lactose, mannitol, or glycerin as the carbon source, the P solubilization efficiency of

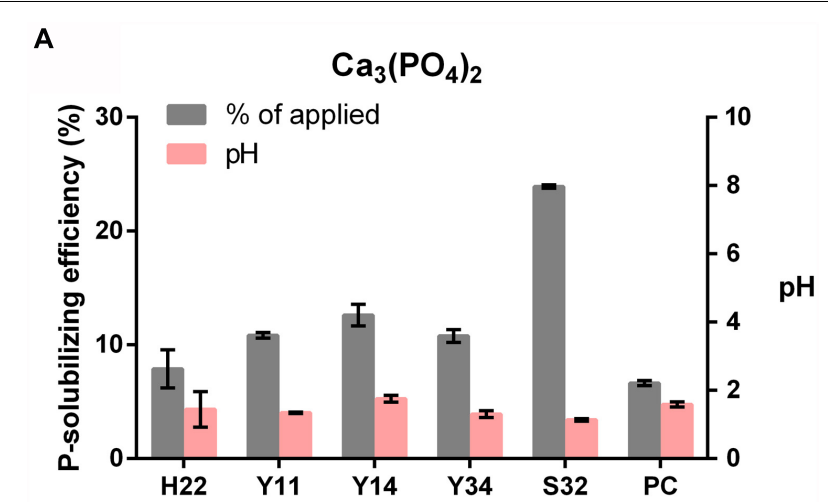

B

\section{Lecithin}

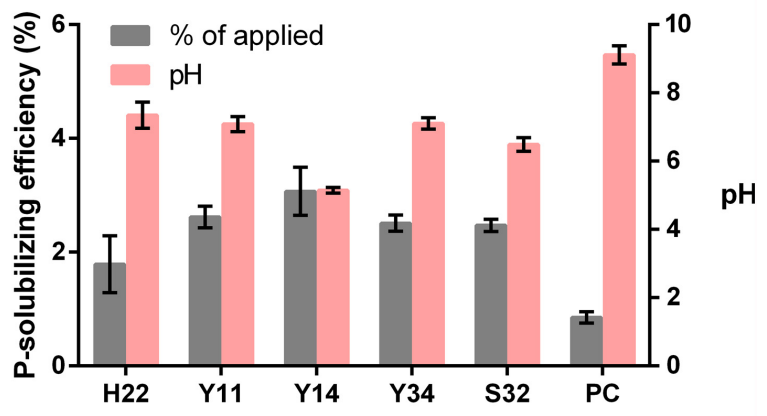

C

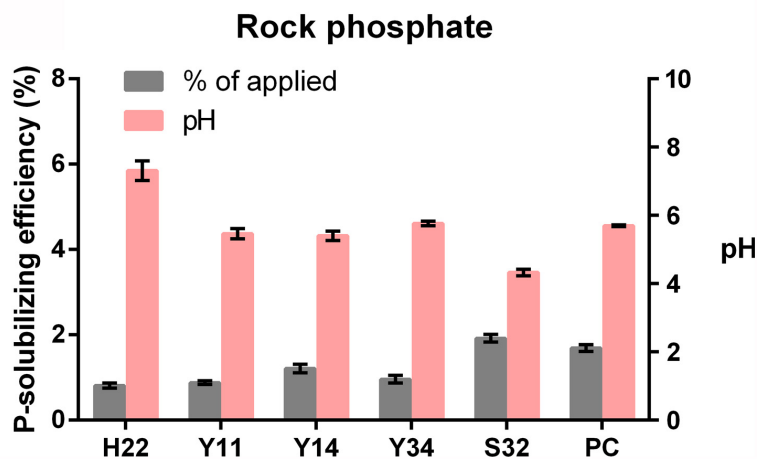

FIGURE 4 | P-solubilization capability of $\mathrm{PSBs}$ with $\mathrm{Ca}_{3}\left(\mathrm{PO}_{4}\right)_{2}$ (A), lecithin (B), and PR (C).

S32 was $24.19,0.75,0.73,8.29,1.30,7.40$, or $5.25 \%$, respectively, (the $\mathrm{pH}$ of the medium was reduced by $3.51,0.23,0.51,1.82,0.73$, 2.23 , or 1.56 , respectively). This result demonstrated that glucose was the best carbon source for assisting the P-dissolving capacity of S32. Notably, we found that sucrose and starch did not differ from the negative control, suggesting that these two saccharides cannot be utilized as carbon sources by S32 (Figure 5C).

To assess the influence of $\mathrm{pH}$ on the $\mathrm{P}$ solubilizing efficiency of $\mathrm{S} 32$, the initial $\mathrm{pH}$ value of the Pi medium was set as 4.0, 5.0, 6.0, 7.0, 8.0, 9.0, or 10.0. After culturing for $24 \mathrm{~h}$, the P-dissolving rate of bacteria S32 in these media was 13.56, 14.10, 22.32, 22.69, $22.51,12.87$, or $12.72 \%$, indicating that the highest $\mathrm{P}$ solubilizing rate occurred at $\mathrm{pH}=7$ (Figure 5D). 


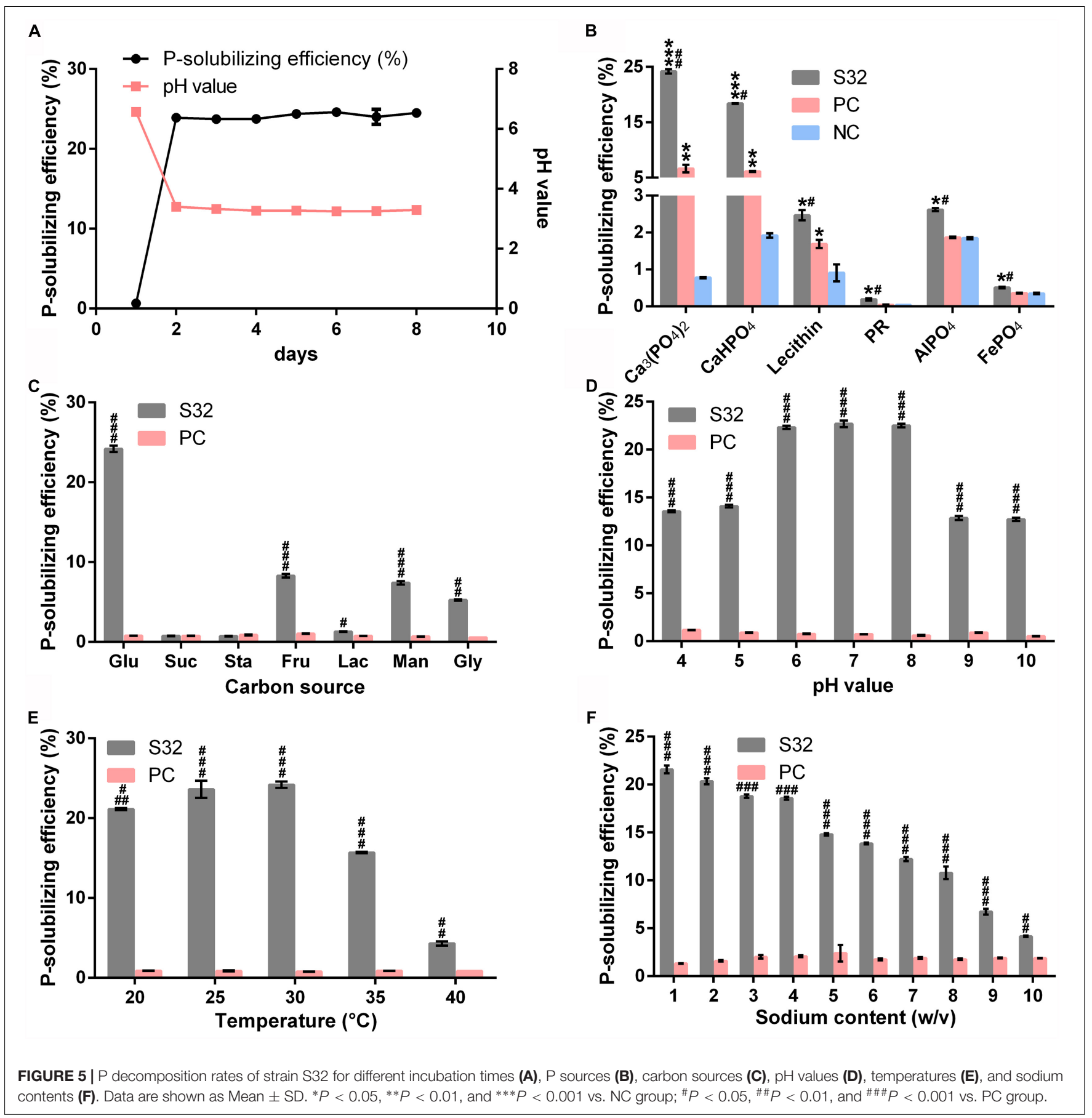

Next, we determined the effect of temperature on the $\mathrm{P}$-dissolving rate of $\mathrm{S} 32$. The $\mathrm{P}$-dissolving rate for $\mathrm{Ca}_{3}\left(\mathrm{PO}_{4}\right)_{2}$ of bacteria S32 after it was cultured for 5 days at 20, 25, 30, 37, or $40^{\circ} \mathrm{C}$ was $21.13,23.16,24.19,15.70$, or $4.30 \%$ (the $\mathrm{pH}$ value of the medium was reduced by $3.15,3.33,3.51,2.73$, or 1.63), respectively. These data demonstrated that the best $\mathrm{P}$-solubilizing efficiency was obtained at $30^{\circ} \mathrm{C}$ (Figure 5E).

The P-solubilizing ratio for $\mathrm{Ca}_{3}\left(\mathrm{PO}_{4}\right)_{2}$ by $\mathrm{S} 32$ in growth medium containing $\mathrm{NaCl}$ with concentrations of $1,2,3,4,5,6$, $7,8,9$, or $10 \%$ was $21.58,20.35,18.79,18.57,14.80,13.85,12.22$,
$10.79,6.73$, or $4.16 \%$ (the $\mathrm{pH}$ value in the medium was reduced by $2.90,2.77,2.58,2.49,2.70,2.54,2.37,2.30,1.87$, or 1.13), respectively. These data suggested that the P-solubilizing capacity decreased with increasing sodium concentration (Figure 5F).

\section{Acid and Alkaline Phosphatase Activity of S32}

The activity of acid phosphatase (ACP) in S32 was $6.94 \mathrm{U} / 100 \mathrm{~mL}$, which was 3.6-fold greater than the positive control As1.223 
$(1.93 \mathrm{U} / 100 \mathrm{~mL})$. The activity of alkaline phosphatase (ALP) in S32 was $4.12 \mathrm{U} / 100 \mathrm{~mL}$, while that of the positive control As 1.223 was $1.90 \mathrm{U} / 100 \mathrm{~mL}$. These results clearly demonstrated that both ACP and ALP activity in S32 were higher than in As1.223.

\section{P-Dissolving Capacity in Experimental and Reclaimed Soil}

The available $\mathrm{P}$ in the experimental soil of the S32 treatment group was increased by $8.85 \mathrm{mg} / \mathrm{kg}$ at 30 days post application, respectively. The difference between the before and after inoculation was significant $(P<0.05)$. Moreover, the available soil $\mathrm{P}$ of the S32 groups at 30 days post application displayed significant differences in many $\mathrm{P}$ fractions (Fe-bound $\mathrm{P}, \mathrm{Ca}-$ bound $\mathrm{P}$, moderately labile Po, and moderately resistant Po), suggesting that the S32 showed multiple P-solubilizing ability in experimental soil (Table 2). We also tested the $\mathrm{P}$-solubilizing rate of S32 in Xiaoyi reclaimed soil which displayed obviously less Po than experimental soil, and the results showed that S32 also displayed a higher P-solubilizing efficiency in many $\mathrm{P}$ fractions (Occluded P, Ca-bound P, moderately labile Po, moderately resistant $\mathrm{Po}$, and highly resistant $\mathrm{Po}$ ) compared to data obtained before S32 inoculation (Table 3). We also found that S32 possessed higher P-solubilizing capacity than PC bacteria.

\section{The Effect of S32 on Plant Growth}

We observed that plant height and dry biomass significantly increased following S32 inoculation. Higher plant height $(14 \mathrm{~cm})$ and heavier dry biomass $(0.58 \mathrm{~g})$ were observed in the S32 inoculated treatments (Table 4) compared with the positive control inoculation groups. In addition, we examined the morphology of the PSB-inoculated rice roots in both experimental and reclaimed soil. The root length, root surface area and volume varied with the different inoculations. Treatment with S32 improved rice root development, especially for the root surface area (Table 5). Generally, greater root length, surface area and volume were found in inoculated compared to positive control rice plants. In addition, we found a higher

TABLE 2 | Experimental soil culture test of strain S32.

\begin{tabular}{|c|c|c|c|c|c|c|}
\hline \multirow{2}{*}{$\frac{\text { Groups }}{\text { P fractions }}$} & \multicolumn{2}{|c|}{ S32 } & \multicolumn{2}{|c|}{ PC } & \multicolumn{2}{|c|}{ NC } \\
\hline & Before & After & Before & After & Before & After \\
\hline Av-P & 6.41 & 15.26 & 6.40 & 8.83 & 6.40 & 6.41 \\
\hline Al-P & 1.66 & 1.04 & 1.55 & 1.58 & 1.64 & 1.64 \\
\hline $\mathrm{Fe}-\mathrm{P}$ & 13.44 & 12.58 & 13.31 & 12.64 & 13.36 & 13.32 \\
\hline Oc-P & 82.50 & 82.14 & 82.25 & 82.48 & 81.84 & 81.82 \\
\hline Ca-P & 113.42 & 105.00 & 112.57 & 112.56 & 116.80 & 116.48 \\
\hline L-Po & 10.76 & 10.44 & 11.21 & 10.76 & 11.34 & 11.28 \\
\hline ML-Po & 38.60 & 34.40 & 38.39 & 37.84 & 38.24 & 38.42 \\
\hline MR-Po & 26.60 & 23.80 & 26.41 & 25.40 & 26.76 & 26.38 \\
\hline HR-Po & 186.36 & 184.66 & 185.49 & 182.42 & 187.34 & 183.84 \\
\hline
\end{tabular}

Distributions of experimental soil $P$ fractions before and after $S 32$ inoculation. Av- $P$, available P; Al-P, Al-bound P; Fe-P, Fe-bound P; Oc-P, Occluded P; Ca-P, Cabound $P$; L-Po, labile organic $P$; $M L-P o$, moderately labile organic $P$; $M R-P o$, moderately resistant organic $P$; HR-Po, highly resistant organic $P$.
TABLE 3 | Experimental and reclaimed soil culture test of strain S32.

\begin{tabular}{|c|c|c|c|c|c|c|}
\hline \multirow{2}{*}{$\frac{\text { Groups }}{\text { P fractions }}$} & \multicolumn{2}{|c|}{ S32 } & \multicolumn{2}{|c|}{ PC } & \multicolumn{2}{|c|}{ NC } \\
\hline & Before & After & Before & After & Before & After \\
\hline$A v-P$ & 4.05 & 12.89 & 4.02 & 6.90 & 4.00 & 4.05 \\
\hline Al-P & 10.56 & 10.02 & 10.50 & 10.22 & 10.38 & 10.52 \\
\hline Fe-P & 32.56 & 29.03 & 33.67 & 32.08 & 33.14 & 33.08 \\
\hline Oc-P & 115.92 & 113.61 & 116.48 & 113.79 & 115.21 & 115.46 \\
\hline $\mathrm{Ca}-\mathrm{P}$ & 69.80 & 65.34 & 67.87 & 69.22 & 71.04 & 70.51 \\
\hline L-Po & 9.00 & 8.36 & 8.83 & 9.36 & 9.03 & 8.76 \\
\hline ML-Po & 19.54 & 17.02 & 18.60 & 16.31 & 19.00 & 19.05 \\
\hline MR-Po & 14.22 & 11.02 & 14.45 & 13.34 & 14.30 & 14.24 \\
\hline HR-Po & 51.60 & 46.44 & 50.62 & 49.88 & 51.22 & 51.06 \\
\hline
\end{tabular}

Distributions of reclaimed soil $P$ fractions before and after $S 32$ inoculation. Av-P, available P; Al-P, Al-bound P; Fe-P, Fe-bound P; Oc-P, Occluded P; Ca-P, Cabound $P$; L-Po, labile organic $P$; ML-Po, moderately labile organic $P$; MR-PO, moderately resistant organic $P$; HR-Po, highly resistant organic $P$.

TABLE 4 | Effect of S32 on the height and biomass of plants in ES or RS.

\begin{tabular}{lcccc}
\hline Treatment & $\begin{array}{c}\text { Plant height } \\
(\mathbf{c m}) \text { in ES }\end{array}$ & $\begin{array}{c}\text { Dry weight } \\
(\mathbf{g}) \text { in ES }\end{array}$ & $\begin{array}{c}\text { Plant height } \\
(\mathbf{c m}) \text { in RS }\end{array}$ & $\begin{array}{c}\text { Dry weight } \\
(\mathbf{g}) \text { in RS }\end{array}$ \\
\hline S32 & $14.56 \pm 0.27^{*}$ & $0.58 \pm 0.08$ & $11.96 \pm 0.20^{*}$ & $0.39 \pm 0.05^{*}$ \\
PC & $12.27 \pm 0.25$ & $0.45 \pm 0.17$ & $9.20 \pm 0.09$ & $0.26 \pm 0.10$ \\
NC & $11.82 \pm 0.35$ & $0.42 \pm 0.05$ & $9.00 \pm 0.11$ & $0.24 \pm 0.05$
\end{tabular}

ES, experimental soil; $R S$, reclaimed soil; $P C$, positive control; $B$. megaterium As1.223; NC, negative control. ${ }^{*} P<0.05$, compared to NC.

$\mathrm{P}$ concentration in both the leaves and roots of plants inoculated with S32, indicating that S32 increased the P uptake for plant growth (Table 6). The effect of PSB inoculation on the release of organic acids has also been determined through examination of the rhizospheric organic acid concentrations. The plants inoculated with S32 released the highest amounts of organic acids compared to the positive control group (Table 7).

\section{DISCUSSION}

In the present study, a total of five PSBs were screened from the reclaimed soils. These PSB isolates may possess the potential to be applied in improving soil recovery and crop production. A higher P-solubility capacity of S32 was observed in the $\mathrm{Ca}_{3}\left(\mathrm{PO}_{4}\right)_{2}$ medium compared to other bacteria and was therefore chosen for further investigation. Its $\mathrm{P}$-solubilization rates for $\mathrm{Ca}_{3}\left(\mathrm{PO}_{4}\right)_{2}$ and lecithin reached 24.19 and $2.47 \%$, which were nearly quadruple and double that of the positive control As1.223, respectively. Furthermore, several insoluble $\mathrm{P}$ sources, such as $\mathrm{CaHPO}_{4}$, lecithin, powdered $\mathrm{PR}, \mathrm{AlPO}_{4}$, and $\mathrm{FePO}_{4}$, could also be dissolved by S32, with P-solubilizing rates of 18.38, 3.07, 0.16, 3.19 , and $0.51 \%$, respectively. Additionally, ALP and ACP could also be found in S32, with higher activities $(6.94 \mathrm{U} / 100 \mathrm{~mL}$ and $4.12 \mathrm{U} / 100 \mathrm{~mL}$ ) than the positive control As1.223. Our study also suggested that S32 grew well and was adaptable due to its dependence on multiple carbon sources and tolerance to a broad range of temperatures, $\mathrm{pH}$ values, and sodium concentrations. It 
TABLE 5 | Effect of S32 on the root growth of plants in ES or RS.

\begin{tabular}{|c|c|c|c|c|c|c|}
\hline \multirow{2}{*}{$\frac{\text { Soil }}{\text { Treatment }}$} & \multicolumn{3}{|c|}{ Experimental soil } & \multicolumn{3}{|c|}{ Reclaimed soil } \\
\hline & $\begin{array}{l}\text { Root length } \\
\text { (cm) }\end{array}$ & $\begin{array}{l}\text { Root surface area } \\
\qquad\left(\mathrm{cm}^{2}\right)\end{array}$ & $\begin{array}{l}\text { Root volume } \\
\left(\mathrm{cm}^{3}\right)\end{array}$ & $\begin{array}{l}\text { Root length } \\
\text { (cm) }\end{array}$ & $\begin{array}{l}\text { Root surface area } \\
\qquad\left(\mathrm{cm}^{2}\right)\end{array}$ & $\begin{array}{c}\text { Root volume } \\
\left(\mathrm{cm}^{3}\right)\end{array}$ \\
\hline S32 & $57.21 \pm 3.56^{*}$ & $56.63 \pm 9.68^{* *}$ & $5.99 \pm 0.25$ & $33.31 \pm 1.65$ & $39.15 \pm 5.14^{*}$ & $3.65 \pm 0.23^{* *}$ \\
\hline PC & $34.52 \pm 6.25$ & $28.45 \pm 5.59$ & $4.50 \pm 0.24$ & $26.85 \pm 3.26$ & $24.69 \pm 3.63$ & $2.62 \pm 0.21$ \\
\hline NC & $25.81 \pm 5.65$ & $25.14 \pm 8.50$ & $3.96 \pm 0.85$ & $22.32 \pm 4.15$ & $23.15 \pm 3.00$ & $2.45 \pm 0.14$ \\
\hline
\end{tabular}

ES, experimental soil; RS, reclaimed soil; $P C$, positive control; B. megaterium As1.223; NC, negative control. $* P<0.05 ; * * P<0.01$ compared to NC.

also indicated that S32 achieved an optimal P-solubilizing rate in the following culture conditions: 5 days incubation, glucose as the carbon source, $\mathrm{pH}=7$, and temperature $=30^{\circ} \mathrm{C}$.

Accumulating reports describe PSBs with the ability to dissolve both Pi and Po. For instance, Li et al. (2013) isolated four Pi-solubilizing bacteria from the plant Anaphalis lacteal, and their P-dissolving rates ranged from 65.24 to $315.36 \mathrm{mg} / \mathrm{L}$ $(\mathrm{D} / \mathrm{d}$ ratio of bacteria with the largest $\mathrm{P}$-solubilizing cycle $=1.33$ ). Wei et al. (2014) isolated two P-solubilizing fungi with rates of 1051.69 and $872.18 \mathrm{mg} / \mathrm{L}$ on $\mathrm{Ca}_{3}\left(\mathrm{PO}_{4}\right)_{2}$. Huang et al. (2010) isolated Pi-solubilizing bacteria with a Po-dissolving content of $537.6 \mathrm{mg} / \mathrm{L}$ and $\mathrm{pH}$ maximal decrease amplitude of 2.79. Lu et al. (2014) screened for Po-solubilizing bacteria with a D/d value of 4.3 and found that the available $\mathrm{P}$ in a medium with $\mathrm{pH}=7$ is $4.8 \mathrm{mg} / \mathrm{L}$. However, the P-dissolving capability of both functions on reclaimed soil has rarely been reported. In the present study, the isolated bacteria S32 displayed higher P-dissolving capacity than the microbes in the above reports. The P-solubilizing cycles for Pi and Po were 4.42 and 5.19, respectively, while the available $\mathrm{P}$ in the Pi and Po media were $1256.67 \mathrm{mg} / \mathrm{L}$ and $13.05 \mathrm{mg} / \mathrm{L}$, respectively. Remarkably, we tested the P-solubilizing efficiency of S32 in Xiaoyi reclaimed soil, and the data showed that S32 also displayed a considerable P-solubilizing efficiency.

TABLE 6 | Mean leaf and roof P concentrations of plants inoculated with S32 and controls in ES or RS.

\begin{tabular}{|c|c|c|c|c|}
\hline Treatment & $\begin{array}{c}\text { Leaf } \mathrm{P} \text { conc. } \\
\text { in } \mathrm{ES} \\
(\mu \mathrm{g} \mathrm{P} / \mathrm{mg})\end{array}$ & $\begin{array}{c}\text { Root } \mathrm{P} \text { conc. } \\
\text { in } \mathrm{ES} \\
(\mu \mathrm{g} \mathrm{P} / \mathrm{mg})\end{array}$ & $\begin{array}{c}\text { Leaf } \mathrm{P} \text { conc. } \\
\text { in } \mathrm{RS} \\
(\mu \mathrm{g} \mathrm{P} / \mathrm{mg})\end{array}$ & $\begin{array}{c}\text { Root P conc. } \\
\text { in RS } \\
(\mu \mathrm{g} \mathrm{P} / \mathrm{mg})\end{array}$ \\
\hline & $200.23 \pm 29.13^{*}$ & $45.12 \pm 5.67^{*}$ & $123.41 \pm 15.51^{*}$ & \\
\hline PC & $143.21 \pm 10.46$ & $31.95 \pm 3.69$ & $80.24 \pm 12.32$ & $28.25 \pm 2.56$ \\
\hline NC & $103.42 \pm 11.39$ & $24.19 \pm 7.90$ & $69.15 \pm 9.54$ & $22.96 \pm 1.62$ \\
\hline
\end{tabular}

ES, experimental soil; $R S$, reclaimed soil; $P C$, positive control; $B$. megaterium As1.223; NC, negative control. ${ }^{*} P<0.05$, compared to NC.

TABLE 7 | Effect of S32 on the organic acid release in ES.

\begin{tabular}{lccc}
\hline Treatment & Oxalic acid (mM) & Citric acid (mM) & Malic acid (mM) \\
\hline S32 & $93.25 \pm 4.02^{*}$ & $52.66 \pm 5.88$ & $83.14 \pm 14.10^{* * *}$ \\
PC & $78.14 \pm 6.84$ & $51.20 \pm 5.08$ & $5.26 \pm 3.68$ \\
NC & $69.00 \pm 4.03$ & $25.35 \pm 2.31$ & $9.25 \pm 2.75$ \\
\hline ES, experimental soil; $R S$, reclaimed soil; $P C$, positive control; $B$. megaterium \\
\multicolumn{2}{l}{ As1.223; NC, negative control. ${ }^{*} P<0.05 ; * * P<0.001$ compared to NC. }
\end{tabular}

Phosphate solubilizing bacteria mainly belong to Bacillus (Babu et al., 2017; Thomas et al., 2018), Pseudomonas (Otieno et al., 2015; Paul and Sinha, 2017), Arthrobacter (Jiang et al., 2019), Agrobacterium (RodrìGuez and Fraga, 1999), Micrococcus (Dastager et al., 2010), Enterobacter (Jiang et al., 2019), Vibrio (Yu et al., 2012), Serratia (Behera et al., 2017), Rhizobium (Korir et al., 2017), Aeromonas (Jha et al., 2012), and Burkholderia (Jha et al., 2012). Several fungi display the same function, including Sclerotium (Thampi and Bhai, 2017), Penicillium (Li et al., 2016), Aspergillus (Yin et al., 2017), and Trichoderma (Lei and Zhang, 2015). Huang et al. (2010) found that Pseudomonas and Pantoea are optimal species for their stable P-solubilizing effects. Son et al. (2006) isolated a P-dissolving Pantoea from the soybean rhizosphere, and soluble $\mathrm{P}$ in its culturing medium reached $900 \mathrm{mg} / \mathrm{L}$. Zhang et al. (2013) isolated another Pantoea from the Caragana microphylla rhizosphere, and rapidly available $\mathrm{P}$ in its $\mathrm{Pi}$ culture media reached $4.45 \mathrm{mg} / \mathrm{L}$. Kaur and Reddy (2013) isolated efficient P mineralizing bacteria and tested their efficacy in plant mineral uptake and soil fertility of an organic field. Amongst 12 PSB isolated from an organic field, two isolates were selected for field inoculation based on their RP solubilizing ability, exudation of organic acids, phosphatase and phytase activity and production of indole acetic acid and siderophores. These isolates were identified as Pantoea cypripedii and Pseudomonas plecoglossicida. These isolates significantly increased yield and total $\mathrm{P}$ uptake in maize. Soil analysis showed that available P, organic carbon and soil enzyme activities were significantly increased (Kaur and Reddy, 2013). Castagno et al. (2011) isolate 50 PSB strains from a constrained environment such as the Salado River Basin in Argentina. Subsequently, they were found to be related to Pantoea, Erwinia, Pseudomonas, Rhizobium and Enterobacter genera, via $16 \mathrm{~S}$ rRNA gene sequence analysis. The most efficient isolate, was identified as Pantoea eucalypti, a novel species in terms of plant growth-promoting rhizobacteria (Castagno et al., 2011). Park et al. (2011) isolated 18 different PSB strains from $\mathrm{P}$ amended and Lead $(\mathrm{Pb})$ contaminated soils were screened for their efficiency in P solubilization. One PSB was chosen for $\mathrm{Pb}$ immobilization and was identified as Pantoea sp. The PSB significantly increased $\mathrm{P}$ solubilization by $49.9 \%$ in the case of Pantoea sp. for $800 \mathrm{mg} / \mathrm{kg}$ of RP addition, respectively, thereby enhancing the immobilization of $\mathrm{Pb}$ by $8.25-13.7 \%$ (Park et al., 2011). These reports strongly suggested Pantoea sp. a potential candidate for highly efficient PSB. In the present study, the soluble $\mathrm{P}$ content in S32 medium reached up to $1256.7 \mathrm{mg} / \mathrm{L}$, 
demonstrating that $\mathrm{S} 32$ possesses a high P-solubilization capacity, even compared to other strains of Pantoea.

Over $80 \%$ of the $\mathrm{P}$ in cropland soil is $\mathrm{Pi}$. Furthermore, $\mathrm{Pi}$ components in various types of soil display significant differences, e.g., calcium and magnesium phosphate are dominant in some types of soil, while ferric and aluminum phosphate are more abundant in others (Yu et al., 2012). In the present study, the aluminum phosphate-dissolving rate of S32 was $145.95 \mathrm{mg} / \mathrm{L}$, which was lower than that of the PSB reported by Wang et al. (2013). However, S32 was able to dissolve multiple insoluble $\mathrm{P}$ sources other than aluminum phosphate. Different level of soluble phosphates in various forms of $\mathrm{P}$ sources affects the solubilization of insoluble phosphates. First, the process of solubilization by the bacteria was documented to be regulated by the external phosphate levels, as also observed for phosphatases (Nahas, 2007). ACP production was reduced while concentration of soluble phosphate was increased (Wang and Lambers, 2019). Second, soil fertilization with $\mathrm{P}$ is important to both plant and microorganism growth. Increasing active exudation from roots provides substantial amount of organic acids that enhance solubilization. After soluble phosphate was exhausted, the solubilization process was triggered, with a consequent increase in soluble phosphate in the soil (Nahas, 2007). In the present study, The $\mathrm{P}$-solubilizing efficiency of $\mathrm{S} 32$ on different $\mathrm{P}$ sources, $\mathrm{Ca}_{3}\left(\mathrm{PO}_{4}\right)_{2}, \mathrm{CaHPO}$, lecithin, $\mathrm{PR}, \mathrm{AlPO}_{4}$, and $\mathrm{FePO}_{4}$, was 24.09, $18.38,2.47,0.19,0.51$, and $2.62 \%$, respectively.

As heterotrophic bacteria, phosphate solubilizers required carbon source and energy for both the synthesis of new cell material and the oxidation of carbon compounds. Rhizosphere soils present water-soluble C compounds mainly as carbohydrates and organic acids and a small portion and amino acids. It was well known that increasing number of microorganisms was associated with the plant rhizosphere due to its carbon concentration (Nahas, 2007). In the present study, by using glucose, sucrose, starch, fructose, lactose, mannitol, or glycerin as the carbon source, the $\mathrm{P}$ solubilization efficiency of S32 was $24.19,0.75,0.73,8.29,1.30,7.40$, or $5.25 \%$, respectively.

S32 inoculation increased plant height and biomass. In addition to $\mathrm{P}$ solubilization activity, $\mathrm{PSB}$ was reported to secrete phytohormones that might have an influence on root growth. The extensive root system increased nutrient uptake from the surroundings, which increased plant biomass (Wang and Lambers, 2019). Soluble organic acids could serve as a source of carbon for microorganisms and subsequently affect the rhizosphere microbial environment, as well as plant growth. The plant root development in rice was affected by the application of PSB. Therefore, we also tested the effect of S32 on rice root growth and organic acid production in experimental and reclaimed soil.

\section{REFERENCES}

Andersen, S. M., Johnsen, K., Sorensen, J., Nielsen, P., and Jacobsen, C. S. (2000). Pseudomonas frederiksbergensis sp. nov., isolated from soil at a coal gasification site. Int. J. Syst. Evol. Microbiol. 50(Pt 6), 1957-1964. doi: 10.1099/0020771350-6- 1957

Babu, S. V., Triveni, S., Reddy, R. S., and Sathyanarayana, J. (2017). isolation and characterization of phosphate solubilizing microorganisms
A plant with S32 inoculation was found to possess fast root growth and release high amounts of organic acids. These results are consistent with the findings of Srivastava et al. (2007) who reported that the addition of PSBs resulted in the release of $\mathrm{P}$ and positively affected plant growth. Moreover, Hoffland et al. (1989) found that increased organic acids in the rhizosphere microbial environment were highly efficient at increasing the P-solubility of PSBs. The root development and plant biomass were highly correlated with the higher availability of P; in addition, PSB application may also have some other beneficial effects, such as phytohormone production.

\section{CONCLUSION}

In conclusion, the bacterium Pantoea sp. S32, possessing high dissolving capacity for both $\mathrm{Pi}$ and Po, was isolated from alfalfa rhizosphere soil in the reclamation area. S32 showed remarkable $\mathrm{P}$-solubilization rates for different $\mathrm{P}$ sources and promoted plant growth, suggesting that the present study provides a potential approach for accelerating minefield recovery and increasing crop output in reclaimed soil.

\section{AUTHOR CONTRIBUTIONS}

QC performed all the experiments, and collected and analyzed the data. SL conceived the idea, analyzed the data, and wrote the manuscript.

\section{FUNDING}

This study was supported by National Key Research and Development Project of China (2017YFD0801204).

\section{ACKNOWLEDGMENTS}

We thank the National Key Research and Development Project of China (2017YFD0801204) for providing funding support for this study.

\section{SUPPLEMENTARY MATERIAL}

The Supplementary Material for this article can be found online at: https://www.frontiersin.org/articles/10.3389/fmicb. 2019.02171/full\#supplementary-material

from maize rhizosperic soils. Bull. Env. Pharmacol. Life Sci. 6, 194-200.

Behera, B., Yadav, H., Singh, S., Mishra, R., Sethi, B., Dutta, S., et al. (2017). Phosphate solubilization and acid phosphatase activity of Serratia sp. isolated from mangrove soil of Mahanadi river delta, Odisha, India. J. Gene. Eng. Biotechnol. 15, 169-178. doi: 10.1016/j.jgeb.2017.01.003

Brady, C. L., Cleenwerck, I., Van Der Westhuizen, L., Venter, S. N., Coutinho, T. A., and De Vos, P. (2012). Pantoea rodasii sp. nov., Pantoea rwandensis sp. nov. and 
Pantoea wallisii sp. nov., isolated from eucalyptus. Int. J. Syst. Evol. Microbiol. 62, 1457-1464. doi: 10.1099/ijs.0.032615-0

Castagno, L. N., Estrella, M. J., Sannazzaro, A. I., Grassano, A. E., and Ruiz, O. A. (2011). Phosphate-solubilization mechanism and in vitro plant growth promotion activity mediated by Pantoea eucalypti isolated from Lotus tenuis rhizosphere in the salado river basin (argentina). J. Appl. Microbiol. 110, 1151-1165. doi: 10.1111/j.1365-2672.2011.04968.x

Chen, Q., Liu, S., Bai, Y., Li, Y., Gao, C., Zhang, Q., et al. (2014). Screening and identification of phosphate-solubilizing bacteria from reclaimed soil in Shanxi mining area. Plant Nutr. Fertilizer Sci. 20, 1505-1516.

Chen, Y., Rekha, P., Arun, A., Shen, F., Lai, W.-A., and Young, C. (2006). Phosphate solubilizing bacteria from subtropical soil and their tricalcium phosphate solubilizing abilities. Appl. Soil Ecol. 34, 33-41. doi: 10.1016/j.apsoil.2005.1 2.002

Colwell, J. (1963). The estimation of the P fertilizer requirements of wheat in southern new south wales by soil analysis. Aus. J. Exp. Agric. 3, 190-197.

Corey, R. B. (1971). A textbook of soil chemical analysis. Soil Sci. Soc. Am. J. 37, 520.

Crooke, W. M., and Simpson, W. E. (2010). Determination of ammonium in Kjeldahl digests of crops by an automated procedure. J. Sci. Food Agric. 22, 9-10. doi: $10.1002 /$ jsfa.2740220104

Dastager, S. G., Deepa, C., and Pandey, A. (2010). Isolation and characterization of novel plant growth promoting micrococcus sp NII-0909 and its interaction with cowpea. Plant Physiol. Biochem. 48, 987-992. doi: 10.1016/j.plaphy.2010.09.006

Deshmukh, A. (2007). Handbook of Media, Stains and Reagents in Microbiology. Oxford: Oxford Book Company.

El Zemrany, H., Czarnes, S., Hallett, P. D., Alamercery, S., Bally, R., and Jocteur Monrozier, L. (2007). Early changes in root characteristics of maize (Zea mays) following seed inoculation with the PGPR Azospirillum lipoferum CRT1. Plant Soil 291, 109-118. doi: 10.1007/s11104-006-9178-0

Gammon, N. (1951). Determination Of total potassium and sodium in sandy soils by flame photometer. Soil Sci. 71, 211-214. doi: 10.1097/00010694-19510300000009

Hoffland, E., Findenegg, G. R., and Nelemans, J. A. (1989). Solubilization of rock phosphate by rape. Plant Soil 113, 161-165.

Huang, J., Sheng, X., and He, L. (2010). Biodiversity of phosphate-dissolving and plant growth promoting endophytic bacteria of two crops. Acta Microbiol. Sinica 50, 710-716.

Jha, A., Sharma, D., and Saxena, J. (2012). Effect of single and dual phosphatesolubilizing bacterial strain inoculations on overall growth of mung bean plants. Arch Agron. Soil Sci. 58, 967-981. doi: 10.1080/03650340.2011.561835

Jiang, Z., Zhang, X., Wang, Z., Cao, B., Deng, S., Bi, M., et al. (2019). Enhanced biodegradation of atrazine by Arthrobacter sp. DNS10 during co-culture with a P solubilizing bacteria: Enterobacter sp. P1. Ecotoxicol. Environ. Safety 172, 159-166. doi: 10.1016/j.ecoenv.2019.01.070

Kaur, G., and Reddy, M. S. (2013). Phosphate solubilizing rhizobacteria from an organic farm and their influence on the growth and yield of maize (Zea mays L.). J. Gen. Appl. Microbiol. 59, 295-303. doi: 10.2323/jgam. 59.295

Korir, H., Mungai, N. W., Thuita, M., Hamba, Y., and Masso, C. (2017). Coinoculation effect of rhizobia and plant growth promoting rhizobacteria on common bean growth in a low P soil. Front. Plant Sci. 8:141. doi: 10.3389/fpls. 2017.00141

Lambers, H., and Plaxton, W. C. (2018). P: back to the roots. Annu. Plant Rev. 48, $3-22$.

Lei, Z., and Zhang, Y.-Q. (2015). Effects of phosphate solubilization and phytohormone production of Trichoderma asperellum Q1 on promoting cucumber growth under salt stress. J. Integr. Agric. 14, 1588-1597. doi: 10.1016/ s2095-3119(14)60966-7

Li, Z., Bai, T., Dai, L., Wang, F., Tao, J., Meng, S., et al. (2016). A study of organic acid production in contrasts between two phosphate solubilizing fungi: Penicillium oxalicum and Aspergillus niger. Sci. Rep. 6:25313. doi: 10.1038/ srep25313

Li, Z., Chen, X., Yang, C., and Li, P. (2013). Screening, identification and solubilizing properties of the endophytic phosphate-solubilizing bacteria isolated from Ana phalis lactea. Acta Prataculturae Sinica 22, 150-158.
Lu, H., Wang, Y., Wang, H., and Zhao, X. (2014). Study on isolation and identification of phosphate-solubilizing bacteria from saline-alkali soil. J. Northeast Agric. Univ. 45, 77-82.

Maharajan, T., Ceasar, S. A., Ajeesh Krishna, T. P., Ramakrishnan, M., Duraipandiyan, V., Naif Abdulla, A. D., et al. (2018). Utilization of molecular markers for improving the P efficiency in crop plants. Plant Breed. 137, 10-26. doi: 10.1111/pbr.12537

Mishra, M., and Goel, R. (1999). Development of a cold resistant mutant of plant growth promoting Pseudomonas fluorescens and its functional characterization. J. Biotechnol. 75, 71-75. doi: 10.1016/s0168-1656(99)00137-6

Mohn, W. W., Wilson, A. E., Bicho, P., and Moore, E. R. (1999). Physiological and phylogenetic diversity of bacteria growing on resin acids. Syst. Appl. Microbiol. 22, 68-78. doi: 10.1016/s0723-2020(99)80029-0

Nahas, E. (2007). "Phosphate solubilizing microorganisms: effect of carbon, nitrogen, and P sources," in Proceedings of the First international meeting on microbial phosphate solubilization, (Berlin: Springer).

Nair, V., Graetz, D., and Portier, K. (1995). Forms of P in soil profiles from dairies of South Florida. Soil Sci. Soc. Am. J. 59, 1244-1249.

Nelson, D. W., Sommers, L. E., Sparks, D. L., Page, A. L., Helmke, P. A., Loeppert, R. H., et al. (1996). Total carbon, organic carbon, and organic matter. Methods Soil Anal. 9, 961-1010.

Nesme, T., Metson, G. S., and Bennett, E. M. (2018). Global P flows through agricultural trade. Glob. Environ. Change 50, 133-141. doi: 10.1016/j.gloenvcha. 2018.04.004

Otieno, N., Lally, R. D., Kiwanuka, S., Lloyd, A., Ryan, D., Germaine, K. J., et al. (2015). Plant growth promotion induced by phosphate solubilizing endophytic Pseudomonas isolates. Front. Microbiol. 6:745. doi: 10.3389/fmicb.2015.00745

Park, J. H., Bolan, N., Megharaj, M., and Naidu, R. (2011). Isolation of phosphate solubilizing bacteria and their potential for lead immobilization in soil. J. Hazard. Mater. 185, 829-836. doi: 10.1016/j.jhazmat.2010.09.095

Paul, D., and Sinha, S. N. (2017). Isolation and characterization of phosphate solubilizing bacterium Pseudomonas aeruginosa KUPSB12 with antibacterial potential from river Ganga. India Ann. Agrarian Sci. 15, 130-136. doi: 10.1016/ j.aasci.2016.10.001

Popp, A., Cleenwerck, I., Iversen, C., De Vos, P., and Stephan, R. (2010). Pantoea gaviniae sp. nov. and Pantoea calida sp. nov., isolated from infant formula and an infant formula production environment. Int. J. Syst. Evol. Microbiol. 60, 2786-2792. doi: 10.1099/ijs.0.019430-0

RodrìGuez, H., and Fraga, R. (1999). Phosphate solubilizing bacteria and their role in plant growth promotion. Biotechnol. Adv. 17, 319-339. doi: 10.1016/s07349750(99)00014-2

Sahu, S. N., and Jana, B. (2000). Enhancement of the fertilizer value of rock phosphate engineered through phosphate-solubilizing bacteria. Ecol. Eng. 15, 27-39. doi: 10.1016/s0925-8574(99)00013-0

Sasser, M. (1990). Identification of Bacteria by gas Chromatography of Cellular Fatty acids MIDI Technical Note 101. Newark, DE: MIDI Inc.

Schnug, E., and Haneklaus, S. H. (2016). "The enigma of fertilizer P utilization," in $P$ in Agriculture: 100\% Zero, eds E. Schnug, and L. De Kok, (Dordrecht: Springer), 7-26. doi: 10.1007/978-94-017-7612-7_2

Son, H. J., Park, G. T., Cha, M. S., and Heo, M. S. (2006). Solubilization of insoluble inorganic phosphates by a novel salt- and $\mathrm{pH}$-tolerant Pantoea agglomerans R42 isolated from soybean rhizosphere. Bioresour. Technol. 97, 204-210. doi: 10.1016/j.biortech.2005.02.021

Srivastava, S., Kausalya, M. T., Archana, G., Rupela, O. P., and Naresh-Kumar, G. (2007). "Efficacy of organic acid secreting bacteria in solubilization of rock phosphate in acidic alfisols," in First International Meeting on Microbial Phosphate Solubilization, eds E. Velázquez, and C. Rodríguez-Barrueco, (Dordrecht: Springer Netherlands), 117-124. doi: 10.1007/978-1-4020-5765$6 \_16$

Surange, S., Wollum Ii, A., Kumar, N., and Nautiyal, C. S. (1997). Characterization of rhizobium from root nodules of leguminous trees growing in alkaline soils. Can. J. Microbiol. 43, 891-894. doi: 10.1139/m97-130

Thampi, A., and Bhai, R. S. (2017). Rhizosphere actinobacteria for combating phytophthora capsici and Sclerotium rolfsii, the major soil borne pathogens of black pepper (Piper nigrum L.). Biol. Control 109, 1-13. doi: 10.1016/j. biocontrol.2017.03.006 
Thomas, S., Mathew, L., and Rishad, K. (2018). Isolation and molecular identification of phosphate solubilizing bacteria, Bacillus licheniformis UBPSB07 capable of enhancing seed germination in Vigna radiata L. Phytomorphology 68, 13-18.

Verhille, S., Baida, N., Dabboussi, F., Izard, D., and Leclerc, H. (1999). Taxonomic study of bacteria isolated from natural mineral waters: proposal of Pseudomonas jessenii sp. nov. and Pseudomonas mandelii sp. nov. Syst. Appl. Microbiol. 22, 45-58. doi: 10.1016/s0723-2020(99)80027-7

Wang, T., Kong, L., Jiao, J., Liu, M., Hu, F., Sun, B., et al. (2013). Screeing of phosphate-solubilizing bacteria in red soil and their acting mechanisms. Acta Pedologica Sinica 51, 373-380.

Wang, Y., and Lambers, H. (2019). Root-released organic anions in response to low $\mathrm{P}$ availability: recent progress, challenges and future perspectives. Plant Soil $1-22$.

Watanabe, F., and Olsen, S. (1965). Test of an ascorbic acid method for determining $\mathrm{P}$ in water and NaHCO3 extracts from soil 1. Soil Sci. Soc. Am. J. 29, 677-678.

Wei, W., Wu, X., and Qiao, H. (2014). Screening and identification of phosphatesolubilizing fungi of pinus massoniana rhizosphere and its application. Sci. Silvae Sin. 50, 82-88.

Yin, Z., Fan, B., Roberts, D. P., Chen, S., Shi, F., Buyer, J. S., et al. (2017). Enhancement of maize growth and alteration of the rhizosphere microbial community by phosphate-solubilizing fungus Aspergillus aculeatus P93. J. Agric. Biotechnol. 2, 1-10.
Yu, Q., Ma, Z., Wang, J., and Wei, L. (2012). Screening of P solubilizing bacteria and its effects on transformation of soil inorganic P fractions. J. Soil Water Conserv. 26, 103-107.

Zhang, Z., Feng, L., Meng, Q., Niu, Y., Niu, W., Fan, J., et al. (2013). Isolation, identification, real-time PCR investigation of an endophytic phosphatesolubilizing bacteria from Caragana korshinskii Kom.roots. Acta Ecol. Sinica 33, 3941-3946. doi: 10.5846/stxb2012101 81450

Zhu, J., Qu, B., and Li, M. (2017). P mobilization in the yeyahu wetland: Phosphatase enzyme activities and organic $\mathrm{P}$ fractions in the rhizosphere soils. Int. Biodeterior. Biodegradation 124, 304-313. doi: 10.1016/j.ibiod.2017. 05.010

Conflict of Interest: The authors declare that the research was conducted in the absence of any commercial or financial relationships that could be construed as a potential conflict of interest.

Copyright (c) 2019 Chen and Liu. This is an open-access article distributed under the terms of the Creative Commons Attribution License (CC BY). The use, distribution or reproduction in other forums is permitted, provided the original author(s) and the copyright owner(s) are credited and that the original publication in this journal is cited, in accordance with accepted academic practice. No use, distribution or reproduction is permitted which does not comply with these terms. 